\title{
Peranan Ibu Bekerja Dalam Menenamkan Kemandirian Anak Usia 4-5 Tahun
}

\author{
Dewi Rizkia Putri', Nurul Fitria Kumala Dewi ${ }^{2}$ \\ 1,2Program Studi Pendidikan Guru Pendidikan Anak Usia Dini; Fakultas \\ Keguruan Dan Ilmu Pendidikan; Universitas Muhammadiyah Tangerang \\ Email : ${ }^{1}$ rizkiaputri24@gmail.com, ${ }^{2 n u r u l f i t r i a k d @ g m a i l . c o m ~}$
}

\begin{abstract}
Abstrak
Penelitian ini meneliti tentang peranan ibu bekerja dalam menanamkan kemandirian anak usia 4-5 tahun. Penelitian ini bertujuan untuk mengetahui kualitas ibu yang bekerja dalam menanamkan kemandirian pada anak, serta untuk mengetahui tingkat perkembangan kemandirian anak usia 4-5 tahun dari status ibu bekerja. Penelitian ini menggunakan metode penelitian kualitatif dengan jenis penelitian studi kasus. Subyek penelitian ini adalah anak usia 4-5 tahun di perumahan wilayah Kutabumi Tangerang. Penelitian ini dilakukan dirumah masing-masing subjek di wilayah Kutabumi Tangerang. Analisis data dilakukan dengan analisis. Hasil penelitian menunjukan bahwa kualitas peranan ibu dan tingkat kemandirian anak bergantung pada efektifitas waktu yang digunakan dan pemilihan pola asuh dalam keluarga.
\end{abstract}

Kata Kunci: Kemandirian Anak, Peranan Ibu Bekerja

\section{Pengantar}

Kehadiran anak mendatangkan kebahagiaan dan membuat semangat bagi orang tua untuk merawat dan memelihara anak agar terpenuhi segala kebutuhan dan perkembangannya. Pengertian anak dalam UU No. 23 Tahun 2002 pasal 1 tentang perlindungan anak, anak adalah seseorang yang belum berusia 18 (Delapan Belas) tahun, termasuk anak yang masih dalam kandungan (Tim Legality, 2017 h.8). Hal ini berarti bahwa anak usia 4-5 tahun masih dapat di kategorikan sebagai anak. Rentang tersebut di sebut juga sebagai usia prasekolah karena anak mulai mempersiapkan diri memasuki dunia sekolah. Kewajiban dan tanggung jawab orang tua menurut pasal 26 adalah untuk: mengasuh, memelihara, mendidik, dan melindungi anak; menumbuh kembangkan anak 
"Ceria"

Jurnal Program Studi Pendidikan Anak Usia Dini

sesuai dengan kemampuan, bakat, dan minatnya; dan mencegah terjadinya pernikahan pada usia anak-anak (Tim Legality, 2017 h.17).

Dalam era globalisasi yang berkembang sangat pesat seperti sekarang, terjadi perkembangan yang cukup kompleks dalam peran dan fungsi ibu yang menyebabkan berkurangnya peran ibu dalam mendidik anak. Salah satu faktor antara lain, karena ibu memutuskan untuk bekerja di luar dengan alasan menambah penghasilan keluarga ataupun untuk mengaktualisasikan diri. Walaupun berada dalam menjalankan berbagai peran sebagai ibu, bekerja dan tidak bekerja tetap memiliki tugas dan tanggung jawab membina pertumbuhan dan perkembangan anak, misalnya: melayani kebutuhan hidup anak, menyiapkan berbagai kebutuhan anggota keluarga, memasak, di samping berbagai tuntutan lain yang muncul dari kehidupan berumah tangga.

Terdapat beberapa faktor yang mempengaruhi keputusan ibu untuk bekerja di luar rumah, faktor yang pertama yaitu aktualisasi diri, seorang ibu rumah tangga sering merasakan kebosanan dan kejenuhan dengan rutinitasnya sehari-hari sehingga dia merasa perlu mengaktualisasikan diri dengan bekerja agar rasa bosan dan jenuh itu hilang. Faktor kedua yaitu minat dan bakat, dengan bekerja di luar rumah, ibu dapat mengembangkan potensi dirinya dengan melakoni hobi yang dimiliki. Ketiga, adalah penghasilan, ibu yang bekerja memiliki penghasilan sendiri untuk memenuhi kebutuhan pribadi atau sebagai tambahan untuk keluarga. Keempat, yaitu tuntutan pekerjaan, sebagian ibu yang bekerja dan meninggalkan anaknya dirumah adalah karena tuntutan pekerjaan sebelum dia menikah, karena memiliki tanggung jawab yang besar dalam status pekerjaannya, menjadikan ibu harus tetap bekerja. Kelima, adalah status ekonomi, seorang ibu bekerja akan mempunyai status ekonomi yang lebih tinggi di banding ibu yang tidak bekerja.

Orang tua khususnya ibu memiliki peran penting yang sangat mendasar dalam menumbuhkan kemandirian anak. Anak yang mandiri dapat dilihat dari tingkah laku baik dalam bentuk fisik, emosional maupun sosial. Contohnya 
"Ceria"

Jurnal Program Studi Pendidikan Anak Usia Dini

secara fisik anak dapat menggunakan peralatan makan sendiri, secara emosional anak mulai dapat mengontrol diri sendiri, mulai pembiasaan, secara sosial anak dapat berinteraksi dengan orang lain, termasuk teman sebaya. Anak dapat berhubungan dengan orang lain sebagai dirinya sendiri. Melalui interaksi dan komunikasi antar ibu dan anak, maka akan berkembang berbagai aspek kepribadian anak termasuk aspek kesadaran terhadap tanggung jawab, perkembangan kemampuan fisik, kognitif, bahasa, sosial emosional, konsep diri, disiplin, kemandirian, seni, moral, dan nilai-nilai agama.

Kemandirian pada diri anak adalah suatu kemampuan yang dimiliki dan dilakukan oleh anak tanpa ingin bergantung dengan orang lain, mempunyai rasa percaya diri dan disiplin, serta bertanggung jawab dalam menyelesaikan tugasnya dan dilakukan atas kesadaran dan kemauan dari dirinya sendiri. Oleh sebab itu, ibu berperan besar dalam mengasuh, membimbing, dan membantu mengarahkan anak untuk menjadi mandiri tidak lain karena masa anak-anak merupakan masa yang paling penting dalam proses perkembangan kemandirian. Meskipun dunia sekolah juga turut berperan dalam memberikan kesempatan kepada anak untuk mandiri, keluarga tetap merupakan pilar utama dan pertama dalam pembentukan karakter anak itu sendiri.

Pada ibu bekerja seharusnya lebih berhati-hati dalam mengambil keputusan yang berhubungan dengan pengasuhan anak, karena untuk memiliki kemandirian secara finansial, sosok ibu harus lebih menekankan kualitas interaksi dengan anak daripada kuantitas. Seorang ibu bekerja bisa melatih kemandirian anak sejak anak masih kecil, sehingga anak-anaknya lebih mandiri dan ia bisa meninggalkan anaknya dan dapat bekerja dengan tenang. Akan tetapi, kenyataannya banyak yang lebih mengutamakan pemuasan kebutuhan materi anak, dengan menuruti segala permintaan anak, memanjakan, dan mengganti ketidak hadirannya bersama anak dengan melimpahi anak mainan-mainan mahal. Sehingga anak tumbuh menjadi pribadi yang manja, susah diatur, dan mempunyai tingkat kemandirian yang rendah. 
"Ceria"

\section{Jurnal Program Studi Pendidikan Anak Usia Dini}

Berdasarkan hasil observasi yang di lakukan di wilayah Kutabumi Pasar Kemis, lebih tepatnya di lingkungan perumahan Graha Teluk Jakarta pada bulan Agustus 2017 peneliti meneliti 2 anak dari 2 keluarga yang berbeda, dengan status Ibu yang sama-sama memiliki pekerjaan diluar rumah.

Kedua orang anak tersebut memiliki ibu yang bekerja namun memiliki kemandirian yang berbeda-beda. Misalnya ketika waktu makan, salah satu dari mereka berdua ada yang mempersiapkan alat makannya sendiri dan mengambil makanannya sendiri, akan tetapi terdapat juga anak yang kurang mandiri dengan meminta dibawakan makanan oleh yang mengasuhnya. Pada hakikatnya, kemandirian merupakan kemampuan seseorang yang dapat berdiri sendiri tanpa bergantung pada orang lain, seperti halnya dalam kemampuan fisik, percaya diri, bertanggung jawab, disiplin, pandai bergaul, mau berbagi, dan mengendalikan emosi. Kemandirian timbul karena kebiasaan sehari-hari yang dilakukan oleh anak, dengan pembiasaan itu akhirnya anak dapat melakukan apa yang diinginkannya secara sendiri tanpa bantuan orang lain.

Berdasarkan hal diatas, penulis menyadari betapa pentingnya peranan ibu dalam menanamkan kemandirian anak, maka penulis akan mendalami karya ilmiah ini dengan judul "Peranan Ibu Bekerja dalam Menanamkan kemandirian anak usia 4-5 Tahun".

\section{Metode}

Pendekatan yang digunakan dalam penelitian ini adalah pendekatan kualitatif. Jenis pendekatan ini merupakan jenis pendekatan yang digunakan untuk menyelidiki dan memahami sebuah kejadian atau masalah yang telah terjadi dengan mengumpulkan berbagai macam informasi yang ada. Metode penelitian kualitatif adalah metode penelitian yang digunakan untuk meneliti pada kondisi obyek yang alamiah (sebagai lawannya adalah eksperimen) dimana peneliti adalah sebagai instrumen kunci, teknik pengumpulan data dilakukan 
"Ceria"

\section{Jurnal Program Studi Pendidikan Anak Usia Dini}

secara trianggulasi (gabungan), analisi data bersifat induktif, dan hasil penelitian kualitatif lebih menekankan makna dari pada generalisasi (Sugiyono, 2013 h.1).

Metode yang digunakan dalam penelitian ini adalah Metode studi kasus. Penelitian studi kasus adalah pendekatan kualitatif yang penelitinya mengeksplorasi kehidupan nyata, sistem terbatas kontemporer (kasus) atau beragam sistem terbatas (berbagai kasus), melalui pengumpulan data yang detail dan mendalam yang melibatkan beragam sumber informasi atau sumber informasi majemuk (misalnya, pengamatan, wawancara, bahan audiovisual, dan dokumen dan berbagai laporan), dan melaporkan deskripsi kasus dan tema kasus (Creswell, 2013 h.135-136).

\section{Hasil dan Pembahasan}

Hasil penelitian dapat memuat berbagai hal meliputi pengungkapan data instrumen penelitian dan hasil analisis data yang diperoleh untuk menjawab permasalahan yang terkait. Penelitian tingkat kemandirian anak usia dini ditinjau dari status kerja ibu dilakukan di Komplek perumahan Graha Teluk Jakarta, Kotabumi Pasarkemis Kabupaten Tangerang. Pengambilan data dilakukan dengan cara mengobservasi anak yang diteliti dan mengambil beberapa sample dari informan terpilih.

\section{Gambaran Umum Tempat Penelitian}

a) Tempat dan lokasi

Komplek Perumahan Graha Teluk Jakarta beralamat di Jl. Raya Cadas - Kukun, Kutabumi, Pasar Kemis, Kabupaten Tangerang, Banten 15560. Lingkungan tempat dilakukannya penelitian berada didalam cluster Sunda Kelapa (SK), pada setiap cluster di komplek perumahan ini memiliki pembatas antar cluster, dan memiliki gerbang pintu masuk sendiri yang dijaga oleh satpam. Di komplek perumahan Graha Teluk Jakarta tidak banyak kendaraan yang berlalu lalang, karena bukan untuk jalanan umum. Oleh karena itu, 
di dalam komplek ini terbilang aman dan nyaman untuk anakanak bermain diluar rumah.

b) Keadaan orangtua

Orang tua merupakan orang dewasa yang menjaga dan merawat anak sedari kecil hingga dewasa, terutama dalam masa perkembangan. Tugas orang tua adalah untuk melengkapi dan mempersiapkan anak menuju kedewasaan dengan memberikan bimbingan dan pengarahan yang dapat membantu anak dalam menjalani kehidupan. Orang tua dari kedua anak yang diteliti masih lengkap, terdiri dari Ayah dan Ibu, dan Ibu dari anak yang diteliti memiliki status pekerjaan diluar rumah, sesuai dengan judul penelitian yang sedang diteliti.

c) Keadaan anak

Anak yang menjadi subjek penelitian memiliki kriteria umur 4-5 tahun dan dalam kondisi sehat tanpa kekurangan suatu apapun. Peneliti mengambil sampel 2 anak dari 2 keluarga yang berbeda didalam lingkungan tersebut.

d) Keadaan kerabat terdekat (tetangga)

Kerabat terdekat atau tetangga yang terpilih menjadi informan pelengkap dalam penelitian ini berasal dari lingkungan yang sama dan bertempat tinggal berdekatan dengan subjek yang diteliti.

e) Pola asuh orangtua

Pola asuh orang tua adalah cara atau metode yang ditempuh orang tua dalam mengasuh dan menerapkan kemandirian kepada anaknya dalam membentuk watak, kepribadian, dan memberikan nilai-nilai bagi anak agar dapat menyesuaikan diri dengan lingkungan.

2. Kualitas peranan ibu yang bekerja dalam menanamkan kemandirian pada anak. 
"Ceria"

Jurnal Program Studi Pendidikan Anak Usia Dini

Sebagai seorang yang penting dalam kehidupan keluarga, maka seorang ibu memiliki tugas-tugas yang harus dijalankan dengan baik. Adapun tugas-tugas peranan seorang ibu antara lain:

a) Mengandung dan melahirkan bayi.

b) Merawat, memelihara, mengasuh, mengajar, dan membina bayi hingga tumbuh menjadi anak, remaja, dan dewasa.

c) Mengajar dan mendidik bayi untuk menerima makanan yang bermanfaat bagi pertumbuhannya.

d) Melatih bayi agar mampu berjalan, berbicara, dan bergaul dengan orangtua dalam keluarga.

e) Melakukan tugas-tugas domestik kerumahtanggaan seperti; memasak, mencuci, dan menjaga kebersihan rumah.

f) Mengembangkan karier untuk mencari nafkah guna menopang ekonomi keluarga (Dariyo, 2013 h.134).

Berdasarkan pendapat diatas, dapat di simpulkan bahwa seorang ibu mempunyai tanggung jawab yang berat dalam memberikan bimbingan kepada anak-anaknya, sebab ibu memiliki kewajiban untuk membentuk kepribadian anak dengan penuh tanggung jawab dan kasih sayang.

Seorang ibu yang bekerja juga memiliki kewajiban untuk mengasuh anak-anaknya disela waktunya setelah bekerja. Untuk dapat memberikan kualitas yang baik, seorang ibu yang bekerja harus dapat mengimbangi waktu antara pekerjaan dan keluarganya. Waktu bertemu ibu dengan anak hendaknya dipergunakan seefektif dan sebaik mungkin. Seorang ibu tetap harus menghadapi anak dengan keceriaan dan keakraban meski dalam kondisi lelah sehabis bekerja. Entah itu untuk kegiatan mendongeng, bermain kreatif, menanyakan apa yang belum tercapai atau sekedar bertanya tentang aktivitas anak seharian tadi. Dengan pendekatan yang efektif dan penuh kasih sayang, dapat mengembangkan kemampuan yang dimiliki anak, termasuk aspek kemandirian.

Selain memanfaatkan waktu sebaik mungkin, seorang ibu juga harus menentukan pola asuh yang tepat dan sesuai untuk anak- 


\section{Jurnal Program Studi Pendidikan Anak Usia Dini}

anaknya. Syaiful Bahri (2014: 51), pola asuh orang tua merupakan gambaran tentang sikap dan perilaku orang tua dan anak dalam berinteraksi, berkomunikasi selama mengadakan kegiatan pengasuhan. Pola asuh orang tua akan menjadi faktor penentu bagi anak, apakah anak dapat tumbuh dan berkembang dengan baik atau tidak. Menurut Olds dan Feldman, Pola asuh orang tua terhadap anak-anaknya sangat menentukan dan mempengaruhi kepribadian (sifat) serta prilaku anak (Helmawati, 2016 h.138). Untuk itu orang tua dituntut harus mengetahui cara pola asuh anak dengan baik dan benar, agar dapat menghasilkan anak yang berkualitas sesuai dengan keinginan orang tua. Kemandirian anak akan tercapai apabila orang tua melakukan upaya melalui berbagai kegiatan yang menunjang mengembangkan kemandirian anak. Dengan pola asuh orang tua yang baik maka anak akan berkembang dalam aspek kemandiriannya.

Dalam penelitian ini, kedua ibu sama-sama menyisihkan waktu luang setelah bekerja untuk anak-anaknya, perbedaannya hanya pada intensitas dan ke efektifan waktu bersama anaknya. Ibu PWS memilih untuk menghabiskan waktu luangnya bersama anakanaknya, dengan bermain, mengobrol dll. Ibu PWS akan mengerjakan tugas-tugasnya saat anak-anaknya tertidur, sedangkan ibu DS membagi waktu luangnya untuk anak dan keperluan dirinya sekaligus.

\section{Tingkat Kemandirian Anak Usia 4-5 Tahun Dari Status Ibu Yang} Bekerja.

Menurut Rich, kemandirian anak dibentuk dari lingkungan keluarga di mana anak tinggal dan dari kesempatan yang di berikan orangtua kepada anaknya untuk melakukan sesuatu secara mandiri (Rahayu, 2013 h.20). Dalam penanaman sifat mandiri pada anak, orang tua dapat melakukan pelatihan kemandirian sejak dini. Dalam proses penanaman sikap kemandirian, orang tua perlu 
"Ceria"

Jurnal Program Studi Pendidikan Anak Usia Dini

mengajarkannya secara perlahan-lahan dan sesuai dengan tahap perkembangan anak.

Tingkat kemandirian anak harus dilalui secara bertahap dengan pengawasan dan bimbingan dari orangtua. Pengertian, pemberian kasih sayang dan pemberian dorongan dapat diberikan dengan menggunakan kata-kata pujian yang tulus tetapi tidak berlebihan. Hal ini dapat menjadi 'rewards' untuk meningkatkan motivasi anak menjadi lebih baik sesuai dengan apa yang diharapkan orangtua dan norma-norma yang berlaku di lingkungan setempat, termasuk dalam meningkatkan motivasi anak untuk menjadi individu yang mandiri dan berkepribadian baik. Berdasarkan hasil penelitian yang telah dilakukan dapat dilihat pada analisis deskriptif bahwa tingkat kemandirian anak usia 4-5 tahun yang diasuh oleh ibu yang bekerja hasilnya tergantung pada pola asuh dan intensitas interaksi dan komunikasi yang diterapkan oleh ibu, selama ibu dan anak sedang bersama-sama.

Dalam penelitian ini, keluarga dari bapak AT dan ibu PWS menerapkan pola asuh demokratis, sedangkan keluarga dari bapak IS dan ibu DS menerapkan pola asuh permisif. Kepribadian kemandirian antara ananda A dan ananda $\mathrm{Q}$ terlihat berbeda, ananda A terlihat lebih mandiri dibandingkan ananda $Q$, meskipun usia ananda $Q$ lebih tua beberapa bulan dibandingkan dengan usia ananda A. Perbedaan kemandirian antara ananda $\mathrm{A}$ dan ananda $\mathrm{Q}$ terlihat dari bagaimana prilaku dan sikap mereka dalam menjalankan kegiatannya sehari-hari.

\section{Kesimpulan}

Dari penelitian di atas dapat diambil kesimpulan bahwa tingkat kemandirian anak usia 4-5 tahun dari status ibu yang bekerja tergantung pada pola asuh, intensitas interaksi dan komunikasi yang diterapkan oleh keluarga 
"Ceria"

Jurnal Program Studi Pendidikan Anak Usia Dini

terutama ibu. Meskipun ibu memiliki status pekerjaan, seorang ibu harus memiliki keahlian untuk memenuhi kewajibannya sebagai ibu rumah tangga dengan cara memberikan sisa waktu luangnya untuk mengasuh, berinteraksi dan berkomunikasi dengan anak. Hal ini bertujuan untuk memenuhi kebutuhan anak akan waktu dan kasih sayang seorang ibu yang kurang karena pekerjaannya.

Untuk mendorong kemandirian, kemampuan sosial anak dan perkembangan lainnya, diperlukan pola asuh yang baik dari orangtua untuk anaknya. Anak menjadi baik atau buruk semua tergantung dari pola asuh orang tua dalam keluarga.

\section{Daftar Acuan}

Creswell, John W. (2015). Penelitian Kualitatif Dan Desain Riset. Yogyakarta: Pustaka Pelajar

Dariyo, Agoes. (2013). Dasar-Dasar Pedagogi Modern. Jakarta: Indeks. Sugiyono. (2013). Memahami Penelitian Kualitatif. Bandung: Alfabeta. Susanto, Ahmad. (2017). Pendidikan Anak Usia Dini. Jakarta: Bumi Aksara. Djamarah, Syaiful Bahri. (2014). Pola Asuh Orang Tua dan Komunikasi Dalam Keluarga. Jakarta:Rineka Cipta.

Legality, Tim. (2017). Undang-Undang Perlindungan Anak. Yogyakarta: Legality. Helmawati. (2016). Pendidikan Keluarga. Bandung: Remaja Rosda. 